\begin{tabular}{|l|l|l|}
\hline \multicolumn{2}{|c|}{ PublisherInfo } \\
\hline \hline PublisherName & $:$ & BioMed Central \\
\hline \hline PublisherLocation & $:$ & London \\
\hline \hline PublisherImprintName & $:$ & BioMed Central \\
\hline \hline
\end{tabular}

\title{
Cell-associated MT1-MMP degrades collagen type I
}

\begin{tabular}{||l|l|l||}
\hline \multicolumn{2}{|c|}{ ArticleInfo } \\
\hline \hline ArticleID & $:$ & 95 \\
\hline \hline ArticleDOI & $:$ & $10.1186 /$ ar-2001-68060 \\
\hline \hline ArticleCitationID & $:$ & 68060 \\
\hline \hline ArticleSequenceNumber & $:$ & 52 \\
\hline \hline ArticleCategory & $:$ & Paper Report \\
\hline \hline ArticleFirstPage & $:$ & 1 \\
\hline \hline ArticleLastPage & $:$ & 3 \\
\hline \hline & & RegistrationDate : 2001-4-11 \\
& $:$ & Received \\
ArticleHistory & & Accepted 2001-7-26 \\
& $: 2001-7-26$ \\
& $:$ & OnlineDate \\
\hline \hline ArticleCopyright & $:$ & Biomed Central Ltd2001-7-26 \\
\hline \hline ArticleGrants &
\end{tabular}




\begin{tabular}{|l|l|l|}
\hline ArticleContext & $:$ & 130753311 \\
\hline
\end{tabular}

Willemijn van der Laan, ${ }^{\text {Aff1 }}$

Affl TNO Prevention and Health, Leiden, The Netherlands

\title{
Keywords
}

\author{
Collagen type I, MT1-MMP
}

\section{Context}

Membrane-type matrix metalloproteinases (MT-MMPs) are, unlike the other MMPs, attached to the cell surface. A recognized function of MT1-MMP is the activation of gelatinase A (MMP-2). However, MT1-MMP itself may also directly exert proteolytic activity. The severe defects observed in MT1-MMP knockout mice, mainly bony malformations, suggest an important role of MT1-MMP in collagen type I turnover. Previous experiments have investigated MT-MMP activity using recombinant, soluble MTMMP. In the present paper, however, a cell culture model was used to investigate the collagenolytic capacity of MT1-MMP attached to the cell surface.

\section{Significant findings}

The results of this study indicate that MT1-MMP is a potent cell associated interstitial collagenase. Cells over-expressing MT1-MMP degraded collagen type I up to four times more efficiently than the control cells. Tissue inhibitor of matrix metaloproteinases (TIMP)-2, but not TIMP-1 inhibited collagenolysis (TIMP-2, unlike TIMP-1, is an efficient inhibitor of MT1-MMP). Collagenolysis was inhibited by ionomycin, an inhibitor of MT1-MMP maturation.

\section{Comments}

The findings of this study suggest an important role of MT1-MMP in pericellular collagen type I degradation. In diseases such rheumatoid arthritis, excessive collagen degradation occurs in the articular cartilage and bone, leading to irreversible joint damage. As a high level of expression of MT1-MMP has 
been observed in the rheumatoid synovium, MT1-MMP may be an important mediator of cartilage and bone erosion. Before MT1-MMP can be considered as an interesting target for joint-sparing therapy, further studies need to be carried out investigating the role of MT1-MMP in cartilage and bone destruction, for instance by studying the proteolytic potential of MT1-MMP on collagen type II and other proteins of the articular cartilage and bone.

\section{Methods}

Immunofluorescence, transfection, tet-off system, ${ }^{14} \mathrm{C}$-labelled collagen films, gelatin zymography, Western blotting

\section{Additional information}

\section{References}

1. Atkinson SJ, Patterson ML, Butler MJ, Murphy G: Membrane type 1 matrix metalloproteinase and gelatinase A synergistically degrade type 1 collagen in a cell model. FEBS Lett. 2001, 491: 222-226.

This PDF file was created after publication. 